\title{
REPRISAL ATTACKS:
}

\section{A THEOLOGICAL REFLECTION OF GENESIS 34 ON REACTIONS TO EVIL AND HUMAN WICKEDNESS IN NIGERIA}

\author{
Miracle Ajah \\ Old and New Testament \\ Stellenbosch University
}

Department of Christian Theology

National Open University of Nigeria

\begin{abstract}
Reprisal attacks have become a global phenomenon. In Nigeria, the post-election crisis of 2011 and the increased suicide bombings in 2012, which have wasted hundreds of lives and property, are some examples. Nigeria's Muslims and Christians mostly co-exist peacefully but periodic flare-ups of sectarian violence and consequent outbursts of retaliation have killed hundreds since independence in 1960. This article presents the results of research on some of the reactions to evil and human wickedness in Nigeria's multi-cultural and multi-religious environment, with particular reference to reprisal attacks. Using the tool of biblical theology, the article aims to proffer possible remedies to reprisal attacks by examining their nature, sources, legitimacy, and effects in the face of political, religious and tribal crises in Nigeria - in the light of the theological ethical considerations of Genesis 34. The tribal hermeneutics of the patriarchal narratives of the Dinah episode, presented Shechem as a city inhabited by the tribe of Hamor. Seen as a weak tribe, Dinah was aggressively assaulted by the tribe of Hamor. Consequently the tribes of Simeon and Levi wreaked vengeance upon the Hamorites in Schechem, in solidarity with their sister tribe Dinah. Unfortunately this bravery of the tribes of Simeon and Levi could only earn them curses and more troubles as an allusion of a final retaliation was meted on them by the Canaanites in the final words of Jacob in Gen 49. The article argues that reprisal attacks cannot forestall or address the socio-ethical problems of evil and human wickedness. The collective roles of the media, religious and governmental bodies, through an objective dissemination of information, and mutual dialogues, including policies that would minimize or check arms proliferation can be possible remedies to evil and human wickedness in society.
\end{abstract}

Key Words: Reprisal Attack; Theological Reflection; Genesis 34; Nigeria; Evil; Human Wickedness; Socio-Ethical; Sectarian Conflicts; Religious Conflicts; Arms Proliferation

\section{Introduction}

Reprisal attacks have become a global phenomenon. In Nigeria, the post-election crisis of 2011 and the increased suicide bombings in 2012, which have wasted hundreds of lives as well as property, are some examples. Nigeria's Muslims and Christians mostly co-exist 
peacefully but periodic flare-ups of sectarian violence or outbursts of retaliation have killed hundreds since independence from Britain in 1960. This article presents the results of research on some of the reactions to evil and human wickedness in Nigeria's multi-cultural and multi-religious environment with particular reference to reprisal attacks.

In reporting about the post-election crisis of 2011 in Nigeria, the Human Rights Watch (May 2011) records:

Deadly election-related and communal violence in northern Nigeria following the April 2011 presidential voting left more than 800 people dead. The victims were killed in three days of rioting in 12 northern states... The violence began with widespread protests by supporters of the main opposition candidate, Muhammadu Buhari, a northern Muslim from the Congress for Progressive Change, following the re-election of incumbent Goodluck Jonathan, a Christian from the Niger Delta in the south, who was the candidate for the ruling People's Democratic Party. The protests degenerated into violent riots or sectarian killings in the northern states of Adamawa, Bauchi, Borno, Gombe, Jigawa, Kaduna, Kano, Katsina, Niger, Sokoto, Yobe, and Zamfara. Relief officials estimate that more than 65000 people have been displaced...

The presidential election divided the country along ethnic and religious lines. As election results trickled in on April 17, and it became clear that Buhari had lost, his supporters took to the streets of northern towns and cities to protest what they alleged to be the rigging of the results. The protesters started burning tyres, and the protests soon turned into riots. The rioting quickly degenerated into sectarian and ethnic bloodletting across the northern states. Muslim rioters targeted and killed Christians and members of ethnic groups from southern Nigeria, who were perceived to have supported the ruling party, burning their churches, shops and homes. The rioters also attacked police stations, the ruling party and electoral commission offices. In predominantly Christian communities in Kaduna State, mobs of Christians retaliated by killing Muslims and burning their mosques and properties.

In a related development, international news media such as CNN, Aljazeera, Reuters, and News Agency of Nigeria (NAN), etc. have chronicled the reprisal attacks in Jos, Nigeria, and the events of increased suicide bombings in 2012 orchestrated by the group: Jamā'atu Ahlis Sunnah Lādda'awatih wal-Jihad (aka: Boko Haram - a Hausa term meaning 'Western education is sinful').

In spite of the attempt of the federal government and the mass media to interpret the incidents as malicious acts by disgruntled and frustrated people full of evil intentions, it was difficult, if not impossible, for many Nigerians, to accept them as non-religious and/or non-tribal. Religious groups in Nigeria have tried their best to exonerate themselves from these unfortunate occurrences. On the surface, it would seem that religious tensions are responsible for most of the violence, however, the reality is far more complex.

So, some of the questions this study will be grappling with are:

- What are the nature and sources of reprisal attacks in Nigeria?

- Can reprisal attacks be legitimate?

- To what extent do they affect the socio-economic development of the nation?

- Does reprisal attack achieve the purpose it aims at?

- What are the possible remedies for sectarian uprisings?

The purpose of this article is to examine the nature and sources of reprisal attacks as a reaction to evil and human wickedness, and to suggest possible remedies for them in the Nigerian context. Adopting a tribal hermeneutics, the article relates the theological ethical 
interpretations of the patriarchal narratives of the Dinah episode in Genesis 34 , to the reprisal attacks in Nigeria. It argues that reprisal attacks cannot forestall or address the socio-ethical problems of evil and human wickedness. The collective roles of the media, religious and governmental bodies, through an objective dissemination of information, and mutual dialogues, including policies that would minimize or check arms proliferation can be possible remedies to evil and human wickedness in the society. These assertions will be validated in this work.

\section{Clarification of Terms}

\section{Reprisal Attack}

The following terms are operationalised for the context of this article: reprisal attack, evil, and human wickedness. The term 'reprisal' is controversial in international law. Onuf (1974:8) defines it as "retaliatory acts that have given rise to retaliatory acts in a potentially infinite series", making reference to Israeli-Arab reprisals. Reprisals in the context of international law were clearly defined in the Naulilaa Case (Portugal v. Germany), summarized as follows:

Reprisals are an act of self-help on the part of the injured states, responding after an unsatisfied demand to an act contrary to international law on the part of the offending State... They would be illegal if a previous act contrary to international law had not furnished the reason for them. They aim to impose on the offending State reparation for the offense or the return to legality in avoidance of new offenses (Mitchell 2001:156).

Mitchell (156) argues that reprisals are related but distinct from the concept of retorsion acts that "are generally not unlawful and which are taken in response to behaviour which itself is not necessarily illegal." In contrast, reprisals involve acts that would normally be illegal. Reprisals are also distinct from another form of self-help, acts of self-defence. Both involve the application of armed force by a State, and share certain preconditions to their use. The difference is the purpose of the two actions. In self-defence, force is applied to counter "an immediate and physical danger" to the State, whereas reprisals coerce another State to abide by international law. Of course, reprisals are also a form of future selfdefence in the sense that they may protect the State from violations of international law in the future.

According to Shane Darcy (2003:184-251), reprisals under international law are prima facie unlawful measures taken by one State against another in response to a prior violation by the latter and for the purpose of coercing that State to observe the laws in force. It is this law enforcement function that places reprisals in the category of sanctions of international law and that grants them legitimacy, despite their inherently unlawful character. To maintain this legitimacy, the act of reprisal must respect the "conditions and limits laid down in international law for justifiable recourse to reprisals; that is, first of all, objectivity, subsidiarity and proportionality." Reprisals taken during a situation of armed conflict are described as belligerent reprisals, while those resorted to during peace time are referred to as peacetime, pacific or armed reprisals. The Covenant of the League of Nations and the Charter of the United Nations classify reprisals as acts endangering peace (www.answers.com).

Our concern in this article is not to discuss reprisals and their legal framework in general, but addressing the issues that give rise to reprisals. Here, 'Reprisal Attacks' refer to the inter and intra-communal and ethnic clashes, ethno-religious violence, sectarian 
uprisings, bomb explosions or suicide bombings, etc. which were orchestrated by aggrieved individuals or groups in retaliation to injuries or injustices received, even in time of peace or the absence of a war situation in a nation.

\section{Evil and Human Wickedness}

An attempt at defining evil and human wickedness is an uphill task. Collins (in Keen and Keen 2004) described the meaning of evil and human wickedness in five ways as follows:

i. A powerful force that some people believe to exist, and which causes wicked and bad things;

ii. All those wicked and bad things that come to happen in the world;

iii. An unpleasant or harmful situation or an activity that is morally bad;

iv. Those who "are very wicked by nature and take pleasure in doing things that harm other people";

v. Something that you think "is influenced by the devil".

Immanuel Kant presented two theses on the subject of evil: philosophical and ethical evaluations:

- Philosophically

Human beings are either wholly evil or wholly good by virtue of whether or not an agent has adopted the moral law as the governing maxim for all of his or her maxims. For either the moral law is the governing maxim for the choice of maxims or it is not; and making the moral law the ground of our maxims is sufficient for moral goodness (Kant 2012 www.iep.utm.edu/rad-evil).

- Ethically

An individual with a morally good character or disposition has adopted a moral maxim as a governing maxim, and incorporates the moral law as a basis for choosing all other maxims. If an agent has done so, then by virtue of making all other maxims compliant with this maxim, these subsequent maxims will be consistent with the moral law. Consequently, the ethical choice facing the moral agent is either to subordinate all other maxims to the moral law, or to subordinate the moral law with every other maxim to an egoistic alternative. The fact is that human agents, although conscious of the moral law, nevertheless do in fact incorporate the occasional deviation from it as part of their individual maxim set. When an agent mis-subordinates the requirements of morality to the incentives of self-conceit (however small it may be), the result is radical evil (Kant 2012 www.iep.utm.edu/rad-evil).

Kant opines that every human being possesses the incentive to adopt the moral law as the governing maxim for maxim choice by virtue of it having arisen out of a basic predisposition to the good.

On the other hand, John Calvin argues:

There could be no knowledge of self without knowledge of God; that all men have a natural awareness of divinity, which is both planted in their minds and made evident through creation. However, man has suppressed or corrupted this knowledge, and confused the creation with the Creator. It is only when men contemplate the greatness of God that they can come to realize theor own inadequacy. God is providentially in control 
of all things that come to pass, including evil things, but this does not make him the author of evil (Calvin Institutes 1960).

Baker's Evangelical Dictionary of Biblical Theology distinguishes between moral evil and physical or natural evil. The term 'moral evil' includes both social offenses (ethics, murder, theft) and cultic sins (those offenses aimed directly against the deity blasphemy, idolatry). Moral evil, therefore, whether its setting be cultic or social, when carried out may be considered a sin; whereas such occurrences which are not under human control or phenomena such as earthquakes, epidemics, tornadoes, etc. are regarded as physical or natural evil.

\section{Genesis 34 (Dinah Episode)}

The Dinah episode in Genesis 34 shows traces of reprisal attack. The account narrates how Prince Schechem, the son of Hamor the Hivite, saw Dinah, Jacob's daughter and had sexual relations with her. On behalf of his son Hamor requested the hand of Dinah in marriage from Jacob her father, indicating willingness for intermarriage between the Israelites and the Hivites, and offering them permanent residency and means of livelihood and property in the land. Jacob waited for his sons' return from work to respond to Hamor and his son Schechem. Simeon and Levi, the elder sons of Jacob, influenced the discussion, and subtly made a condition of circumcising the Hivites as the only ground for accepting the marriage proposal. Hamor and Shechem did not waste time in accepting the condition, and convinced their people to consent because of the influence they had on them, noting that thus all the possessions of the Israelites would be theirs. On the third day after their circumcision, when the Hivites were in pain, Simeon and Levi attacked and killed all the males of the Hivites, including Hamor and Shechem, and took Dinah, their sister home with them, plundering the Hivites utterly and retorting: "Why should he treat our sister as a harlot?" The story concludes with a passive condemnation of their actions by their father Jacob, who expressed fear of reprisals from the Canaanites and the Perizzites.

The tribal hermeneutics of the patriarchal narratives of the Dinah episode presented Shechem as a city inhabited by the tribe of Hamor. Dinah, seen as a weak tribe, was aggressively assaulted by the tribe of Hamor. Consequently the tribes of Simeon and Levi wreaked vengeance upon the Hamorites in Schechem, in solidarity with their sister tribe Dinah. Unfortunately this bravery of the tribes of Simeon and Levi could only earn them curses and more troubles as an allusion of a final retaliation was meted on them by the Canaanites in the final words of Jacob in Genesis 49.

Using historical methodologies, Gerhard von Rad (1972) argues that the narrative does not report actual events in the family life of Leah and Jacob, but rather recalls a 'prehistoric conflict' in early Israelite tribal history. The narrative seems to go back to the time when Israelite tribes were not yet settled in Palestine but on their way in search of new pasture. Grounded in 'some catastrophe' related to territorial dispossession, the personalized saga describes that Shechem "has fallen in love with the girl, Dinah". It emphasizes Shechem's "great love for the girl, which brooks no hindrance". In fact, Von Rad claims: "The figure of Shechem is made more human for the reader" than the brothers who "purify the honour of their violated sister at the cost of a morally ambiguous deed." Thus, from Von Rad's historical perspective, the story recalls the departure of the tribes of Simeon and Levi from the territory around Shechem. Rape is not an issue in this past.

Feldman (2004), siding with a literal interpretation of the text, is of the opinion that the fact that the biblical text speaks of the sons of Jacob as plundering the city "that had defiled 
their sister" (Gen 34:27) indicates that the crime had been committed not merely by Shechem, but by others as well, which would presumably justify the mass execution of the inhabitants. Jacob then told Simeon and Levi that they had brought trouble upon him by making him odious to the inhabitants of the land, and he expressed the fear that they would attack him. The narration was silent on the eventual reactions of the Hivites or their neighbouring tribes on this attack.

Whichever way we look at the story, whether as a figurative tribal representation or the actual account of a rape incident, the lesson is the same in terms of the interpretation of the reactions to evil and human wickedness in the society. Our focus here hinges more on interpreting the threefold segmentation of the Dinah episode, and the lessons we make out of it in addressing the problem of reprisal attacks in society.

\section{Interpreting the Threefold Segmentation of the Dinah Episode}

We can present the interpretation of this Dinah episode in three-fold segmentation as it concerns Dinah, Schechem and Jacob's family, as follows:

\section{- Dinah}

Reading Genesis 34, one is confronted with problems of injustice, rape and murder, and how the key players in the episode tried to deal with them. Who was responsible for what happened? The text says: "Dinah ... went out to see the daughters of the land" (v.1). The word לִרְאו - to see (BDB 906), can be understood in several ways, namely: i) to observe, learn about them and their lives, ii) to visit her friends, and iii) a play on verse 2, "Schechem saw her" (same verb). This is where it all started. According to a medieval biblical commentator, Dinah's egress represents the wandering soul, which travels beyond its enclosure. In the literal context, the "wandering curiosity of Dinah" was blamed because she departed from her father's home, where the young girl ought to have remained enclosed. It further argued clearly that what she suffered eventually was not a case of simple fornication but a case of rape (Schroeder 780). Luther and Calvin believed that Dinah sinned through curiosity by leaving the house without her mother's permission. They considered her rape to have been punishment for disobedience and curiosity, but they distanced themselves from the idea that God caused the rape. Though Dinah sinned through disobedience, they believe that she did not share Shechem's guilt for the rape itself. The weak woman suffered the adulterer's force and violence which she could not drive away (Schroeder 782).

Apparently, the only offense committed by Dinah in this episode was “... went out to see...", because throughout the episode, her voice is not heard, nor any of her actions recorded. Instead, she becomes the centre of all kinds of activities henceforth. Schechem ...

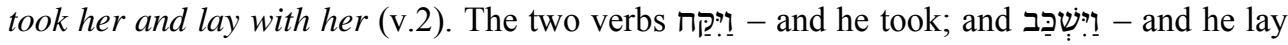
(BDB 1011), express one action, showing intensity in meaning, namely: to take by force, violate, rape, force to sleep with, and thereby defiling her. Furthermore, Schechem's feeling toward Dinah is repeated three times: "And he was deeply attracted to Dinah" (v.3); "So Shechem spoke to his father Hamor, saying, "Get me this young girl for a wife"" (v.4); "the soul of my son Shechem longs for your daughter," (v.8). In the Patriarchal and Ancient Near Eastern culture, it was all about men's rights and little about women's freedoms or feelings (Utley, bible.org). Schechem and his father would not allow Dinah to have a say. 
Not even an apology was extended to her for the assault received, but a marriage proposal to her parents, which looks like a double assault. On the other hand, Jacob and his sons did not help matters. They did not consider her feelings. What they could do was to issue conditions for giving their daughter in marriage whether covertly or overtly. In this light, Sternberg (480) argued that in terms of plot dynamics, Dinah remains a patient and a catalyst, not an agent proper; in terms of voice and viewpoint, an object, not subject, of consciousness. And so she must stay, on pain of throwing the given narrative and its narrative art out of focus. To be sure, the characters in focus were all male, she female. The problem here transcends feminism, but includes every downtrodden and voiceless population.

\section{- Schechem}

The city of Schechem inhabited by the tribe of Hamor, did what was consistent with their customs and traditions. They loved to cherish beauty, and show affection to what appealed to their emotions. The way and manner Schechem went about it brought the problem. Some opinions presented Schechem in a light that was far from completely negative (Feldman 255). These opinions posited that Genesis 34:3 recorded that he did not merely have relations with Dinah but that he became deeply attached to her, loved her, appealed to her emotions and expressed his readiness to give whatever would be asked of him in order to marry her, in verses 11-12. Schroeder (786) enlarges the culprits of the Dinah episode by arguing that though Dinah was innocent of the guilt incurred by the assault, Shechem was not alone in his guilt. His indulgent parents were also at fault for raising him without discipline. Shechem's father, Hamor, participated in the sin by asking Jacob to permit Dinah to marry his son. Both Shechem and Hamor should have repented, asked Jacob's forgiveness, and returned the girl to her father. Shechem's crime was magnified by his failure to repent and by the audacity of his request to marry Dinah. The men of the region also made themselves participants in the crime by complying with Shechem's request that they be circumcised so that Shechem could retain Dinah as his wife, and the allusion of their dispossessing the Israelites eventually (cf. v.23).

Schechem and his people were severely punished for this offense. They were tricked into believing that the family of Jacob had accepted their marriage proposal; when they were asked to circumcise every male to enable them marry the Hebrew. Even though Hebrew law (Deut. 22:28-29) provided that a rapist marry an unmarried victim or pay a fine to her father, Luther believed that in the household of Jacob and in the surrounding region, the rape of a virgin was a capital offense. Since rape was an offense against natural law, human laws have always provided for the severe punishment of rapists. The rape of a virgin was a capital crime in itself by all law, divine and civil, as the rape of Helen, for example, was the cause of the destruction of Troy, and in all ages this crime had been punished in a fearful manner. The rape of a virgin was such a heinous crime that it was usually followed by bloodshed. Rape and the defilement of virgins, have never passed by without bloody slaughter, and this deed was an example (Schroeder 787).

\section{- Jacob's Family}

The news of the rape of Dinah was a trial that took Jacob and his family by surprise, overwhelming him with grief. Jacob heard that Schechem had violated (טִֵֵ̣) his daughter. The verb טִ̣n denotes that which is viewed as unclean according to God's law; she had 
been defiled, disgraced and dishonoured by Schechem. The expected response would be anger or rage; but Jacob remained silent. He appears too indifferent or confused to act decisively. When the leader does not act decisively, the younger zealots will, and often with disastrous results (NetBible Gen. 34:5).When Jacob's sons heard it, they were mortified

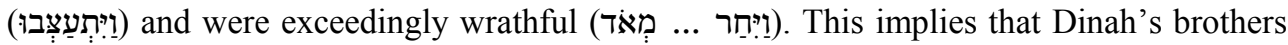
were very angry and aggrieved because of the disgraceful thing done to their sister and the senseless disregard for the moral standards of Jacob and his religious tradition. According to a NetBible commentary of Genesis 34:6, the Hebrew verb עָעַב ('atsav) from where we get context: (1) "to be injured" (Ps 56:5; Eccl 10:9; 1 Chr 4:10); (2) "to experience emotional pain; to be depressed emotionally; to be worried" (2 Sam 19:2; Isa 54:6; Neh 8:10-11); (3) "to be embarrassed; to be insulted; to be offended" (to the point of anger at another or oneself; Gen 6:6; 45:5; 1 Sam 20:3, 34; 1 Kgs 1:6; Isa 63:10; Ps 78:40). This third category develops from the second by metonymy. In certain contexts, emotional pain leads to embarrassment and/or anger. In this last use, the subject sometimes directs his anger against the source of grief (see especially Gen 6:6). The third category fits best in Genesis 34:7 because Jacob's sons were not merely wounded emotionally. On the contrary, Shechem's action prompted them to strike out in judgment against the source of their distress.

Commenting on the action of the sons of Jacob, John Calvin (2000-2013) opined that Shechem, indeed, had acted wickedly and impiously; but it was far more atrocious and wicked that the sons of Jacob should murder a whole people, to avenge themselves of the private fault of one man. It was by no means fitting to seek a cruel compensation for the levity and rashness of one youth, by the slaughter of so many men. Again, who had constituted them judges that they should dare, with their own hands, to execute vengeance for an injury inflicted upon them? Perfidy was also superadded, because they proceeded, under the pretext of a covenant, to perpetrate this enormous crime.

The aftermath of the revenge which the sons of Jacob meted out to Schechem and his tribesmen became very disastrous. Testing their revenge against the backdrop of objectivity, subsidiarity, and proportionality, one is left with an open possibility of an unending cycle of reprisals between the two reviled families or tribes. Hence the comment of Jacob, when he said, "You have brought ruin on me by making me a foul odour among the inhabitants of the land - among the Canaanites and the Perizzites. I am few in number; they will join forces against me and attack me, and both I and my family will be destroyed!" (NetBible). At the end of the day, Simeon and Levi, who had led in the reprisal attack, did not receive commendation for their actions, instead curses. In the final speech of Jacob when he was blessing his children, he said to Simeon and Levi:

Simeon and Levi are brothers; weapons of violence are their knives! O my soul, do not come into their council, do not be united to their assembly, my heart, for in their anger they have killed men, and for leisure they have hamstrung oxen. Cursed be their anger, for it was fierce, and their fury, for it was cruel. I will divide them in Jacob, and scatter them in Israel! (Gen 49:5-7 NetBible).

\section{Reprisal Attacks in Nigeria: Sources, Legitimacy, Effects and Possible Remedies}

This section discusses the common sources of reprisal attacks in Nigeria, their legitimacy, effects and possible remedies in the midst of a multi-religious and ethno-cultural 
environment. Three major examples of reprisal attacks in Nigeria between 2011 and 2012 fully covered by both local and international media were: 2011 post-election crisis (violence began with widespread protests by supporters of the main opposition candidate, with the reprisals that followed, reported earlier in this article); unprovoked bombing of three churches in Kaduna leading to retaliatory attacks, and the Fulani versus Berom crisis in Jos, amidst claims of reprisals and counter reprisals. Common sources of these cases include: ideological reasons, human rights abuses, media roles, illiteracy and poverty. Although these are informed assumptions without claiming very substantial accuracy about the empirical aspects involved, this work concerns itself with the normative issues, given certain presumed facts.

Most reprisal attacks in the country are traceable to the ideological agenda of the sponsors, and not necessarily the ideas of the executors. Virginia Held (1997:189) was right when she argued that agents carrying out political violence were greatly influenced by their beliefs about what is politically right and wrong, and their beliefs about these matters were formed in the contexts of cultural influences, economic interests, religious teachings and beliefs. In the Dinah episode, what informed the reprisal attack on the city of Schechem transcends the raping of Dinah, but was informed by a religio-cultural ideology that a heathen nation (who were also labelled 'uncircumcised') cannot intermarry with the Hebrews (cf. Deuteronomy 22:21f). Allowing the marriage would have been compromising the moral standards and religious traditions of the patriarchs. Trustees of these ideologies are the elite's minority, and not the poor masses. For example, the brutal insurgencies of the Boko Haram (the group that claims responsibility for most of the suicide bombings in the north), are ideologically motivated, which transcends any other possible cause. Their nickname is a pointer to their ideology, which is: "Western education is sinful". According to Martha Crenshaw (1981:384), "Terrorism is essentially the result of elite disaffection; it represents the strategy of a minority, who may act on behalf of a wider popular constituency who have not been consulted about, and do not necessarily approve of, the terrorists' aims or methods." In Nigeria, who are these elite minorities aiding and abetting reprisals in sectarian violence and other vices? Trading blame and counter blame among religious, political and ethnic leaders are all you find in the news media in attempts to unravel the mystery behind the problem. To say the least, any ideology that does not consider or accommodate another (whether religious, political, economic, or cultural) is the major reason for the eruption of sectarian violence in the society.

Abuse of human rights precedes reprisal attacks. In the Dinah episode Simeon and Levi came to revenge for their sister because they felt her rights had been abused. The three incidents of reprisal attacks cited above are linked to abuses of human rights. Those who engaged in sectarian violence and reprisals felt that their rights were being trampled upon. For example, some opinions in defence of Boko Haram, point to economic deprivations and underdevelopment of northern Nigeria as the reason for their uprisings, similar to the upsurge of the militants in the Niger Delta region (www.hrw.org). But can one refer correctly to Boko Haram as a reprisal or a pursuit of an ideological agenda? For the Fulani and Berom crisis, there is a claim and counterclaim of human rights abuses in connection with the ownership of land. The Human Rights Watch urged the Nigerian government to take concrete steps to end policies that discriminate against 'non-indigenes' (www.hrw.org). Furthermore, the fallout of frustration with corruption and the attendant social malaise of poverty and unemployment contribute to the problem (www.wikipedia.org). It is easier to recruit an idle, poverty-stricken person into terrorism as a means of livelihood, than recruiting a person in a worthwhile employment. Finally, some news media reportage has 
not helped matters. In a study carried out in the USA, substantiated charges were levelled against the media for promoting a culture of violence, which has contributed to the high levels of violent acts which take place in the US (Held 191). The situation is not different in Nigeria.

Under which ground should reprisal attacks be considered legitimate? In the Dinah episode Jacob's family considered reprisal as a suitable response to the abuse and injustice suffered by their sister. A cross-section of reprisal attacks in Nigeria follow the same line of thought. According to the Legal Dictionary, "To be considered legitimate, reprisals must be taken in response to prior illegal attacks. A reprisal is a form of self-defence and can be used only as a last resort; it must be executed with the view of restoring a sense of equilibrium in international relations and ensuring future compliance with legal norms". But testing reprisals against the background of objectivity, subsidiarity, and proportionality, it states, "The notion of proportionality is important in reprisals. Any response from an aggrieved country must be proportional to the injury it sustained" (Legal Dictionary). The UN General Assembly in its 1970 Declaration on Principles of International Law declares: "States have a duty to refrain from acts of reprisal involving the use of force" (Resolution $2625 \mathrm{XXV})$.

Can the legitimacy of reprisal attacks eliminate their causes? Some commentators suggest that the execution or threat of reprisal encourages an adversary to refrain from or discontinue violations of the laws of war; in other words, reprisals provide an important deterrent or compliance effect (Mitchell 171). On the other hand, one could see that in the Dinah episode Simeon and Levi did not achieve a lasting solution after all, because they were cursed eventually by Jacob, their father, for this singular action (Gen 49:5-7). Howbeit, reprisal attacks usually lead to counter-reprisal attacks as we have seen in the Nigerian experience since 2011. The entire polity is aggravated with ensuing cold war along the lines of religion, ethnicity and politics. Thousands of lives and property have been wasted through reprisal attacks. The level of insecurity in the land (especially in the north) has affected economic activities and investments from foreign nations. Recently, the northern Governors cried out that the current insecurity in the North was impoverishing it (www.vanguardngr.com). Mutual trust and collaborations are waning, a situation that might affect the nation adversely in future, amidst the call for rethinking the "Nationhood of Nigeria" by different groups (www.smc.edu.ng; www.punchng.com).

So, what is the way out of reprisal attacks as a response to evil and human wickedness in Nigeria? Any meaningful solution should be mindful of the fact that the country is a multi-religious, multi-cultural/ethnic, and multi-political nation. Religious groups, tribal organizations, political parties, governmental bodies, and the news media have roles to play in order to forestall the increasing waves of reprisal and their attendant causes. Possible remedies for reprisal attacks in Nigeria include: sincere dialogue, reconciliation, forgiveness, tolerance, education, good governance, balanced reporting by the news media and positive contributions from elder statesmen. The first response to an offense should not be a counter offense or violence but should be a sincere dialogue with the offender. It was once said that two wrongs cannot make a right. In the Dinah episode, the dialogue between the houses of Jacob and Hamor was a hypocritical one. Both parties were insincere. While the house of Jacob was biding its time for revenge, it gave a false condition for reconciliation; on the other hand, the house of Hamor was not sincere in their intermarriage proposal because they were also biding their time to subjugate the Hebrews with their possessions (cf. Gen 34:13,18-23). Hence, the calamity that followed. At the root of any meaningful dialogue and reconciliation, there must be genuine openness and forgiveness, 
and not a superficial consent to peace. The chairman of the Truth and Reconciliation Commission in South Africa, Desmond Tutu once said, "Without forgiveness there can be no future for a relationship between individuals or within and between nations" (BBC 53). "Forgiveness does not change the past, but it does enlarge the future" (Boese). Martin Luther King added:

We must develop and maintain the capacity to forgive. He who is devoid of the power to forgive is devoid of the power to love. There is some good in the worst of us and some evil in the best of us. When we discover this, we are less prone to hate our enemies (www.brainyquote.com).

Good governance that guarantees quality education and equitable distribution of the nation's resources in providing basic amenities can contribute in ameliorating the sufferings of Nigerian people, thereby forestalling the violent agitations from different communities. In addition, policies that would minimize or check arms proliferation, foster religious cooperation and tolerance, improve social services, and encourage private enterprise can be possible remedies to evil and human wickedness in the society. According to Nelson Mandela, "Overcoming poverty is not a task of charity; it is an act of justice. Like Slavery and Apartheid, poverty is not natural. It is man-made and it can be overcome and eradicated by the actions of human beings. Sometimes, it falls on a generation to be great; you can be that great generation" (www.goodreads.com). Elder statesmen in Nigeria should play positive roles in shaping the mindset of their people towards tolerance and good neighbourliness. In the Dinah episode, the elder statesman, Jacob, played a dormant role, only to blame the evil actions of the younger generation later. Nelson Mandela and Desmond Tutu played positive roles in South Africa, thereby averting nationwide reprisals that could have sent the whites packing. Nigeria's elder statesmen should be up-coming in playing roles that would earn them international Nobel Peace Prizes.

\section{Conclusion}

Reprisal attacks cannot forestall or address the socio-ethical problems of evil and human wickedness. The theological ethical considerations of Genesis 34, the Dinah episode, have shown that people who resort to reprisal attacks as a response to an offense received and as a reparation for a loss suffered, do not receive satisfaction but a cycle of reprisals with the enemy. Common sources of reprisal attacks highlighted were: ideological reasons, human rights abuses, media roles, illiteracy and poverty. On the legitimacy of reprisal attacks, the article argued that testing reprisals against the background of objectivity, subsidiarity, and proportionality and their attendant consequences, they remain a difficult option. In the light of these, it is recommended that the collective roles of the media, religious and governmental bodies, through an objective dissemination of information, and mutual dialogues, including policies that would minimize or check arms proliferation, foster religious cooperation and tolerance, improve social services, and encourage private enterprise can be possible remedies to evil and human wickedness in society. 


\section{BIBLIOGRAPHY}

Amaechi, Rotimi 2012. "To your tents O Nigerians.” www.smc.edu.ng/dispics, accessed on $13 / 12 / 12$.

BBC 2000. "Truth and reconciliation", BBC Focus on Africa Magazine, January-March:53.

Boese, Paul. http://www.brainyquote.com/ accessed on 12/12/12.

Brown, F, et al. 1997. The Brown-Driver-Briggs Hebrew and English Lexicon: With an appendix containing the biblical Aramaic coded with the numbering system from Strong's concordance of the Bible, [si] Hendrickson Publishers.

Calvin, John 1960. Institutes of the Christian Religion. Transl. Ford Lewis Battles. 4 vols. Philadelphia: Westminster.

Calvin, John 2000-2013. John Calvin's Bible Commentary, Genesis 34. http://www.ewordtoday.com/comments/genesis/calvin/genesis1.htm accessed on 18/11/13.

CNN 2012. http://articles.cnn.com/2012-06-17/africa/world_africa_nigeria-churchbombings_1_car-bomb-boko-haram-church-bombings?_s=PM:AFRICA accessed on $8 / 10 / 12$.

Crenshaw, Martha 1981. "The Causes of Terrorism" Comparative Politics, Vol. 13, No. 4:379-399.

Darcy, Shane 2003. 'The Evolution of the Law of Belligerent Reprisals', in Military Law Review 175:184-251.

Darcy, Shane 2012. "Retaliation and Reprisal", http://ssrn.com/abstract=2172573 accessed on 22/11/12.

Feldman, Louis H 2004. "Philo, Pseudo-Philo, Josephus, and Theodotus on the Rape of Dinah", The Jewish Quarterly Review JQR94, No. 2:253-277.

Held, Virginia 1997. "The Media and Political Violence" The Journal of Ethics, Vol. 1, No. 2:187-202.

Human Rights Watch 2011. http://www.hrw.org/news/2011/05/16/nigeria-post-electionviolence-killed-800 accessed on 9/10/12.

Kant, Immanuel 2012. "Radical Evil," in Internet Encyclopedia of Philosophy. http://www.iep.utm.edu/rad-evil/ accessed on 18/11/13.

Keen, Daniel E \& Keen, Pamela R (eds.) 2004. Considering Evil and Human Wickedness. Oxford: Inter-Disciplinary Press.

Kugel, James 1992. "The Story of Dinah in the Testament of Levi". The Harvard Theological Review, Vol. 85, No. 1:1-34.0

Leadership Newspaper 2012. http://www.leadership.ng/nga/articles/27588/2012/06/18/72

Mitchell, Andrew D 2001. "Does One Illegality Merit Another? The Law Of Belligerent Reprisals In International Law" in Law Of Reprisals, 155-177 (JSTOR).

NetBible 1995. http://www.bible.org/ accessed on 8/10/12.

Reuters 2012. http://www.reuters.com/article/2012/06/17/us-nigeria-violenceidUSBRE85G0CR20120617/ accessed on 8/10/12. 
Schroeder, Joy A 1997. "Luther's Interpretation of the Rape of Dinah" The Sixteenth Century Journal, Vol. 28, No. 3:775-791 (JSTOR).

Sternberg, Meir 1992."Biblical Poetics and Sexual Politics: From Reading to Counter Reading," Journal of Biblical Literature, Vol. 111, No. 3:463-488.

United Nation General Assembly 1970. Resolution 2625 XXV.

Von Rad, Gerhard 1972. Genesis: A Commentary, 3rd rev. (ed.) Philadelphia: Westminster Press.

William, Williams C 1996. "Evil", in Elwel, Walter A (ed.). Baker's Evangelical Dictionary of Biblical Theology. http://www.studylight.org/ accessed on 18/11/13.

\section{Websites}

http://en.wikipedia.org/wiki/Boko_Haram, accessed on 5/12/12.

http://legal-dictionary.thefreedictionary.com/reprisal, accessed on 11/12/12.

http://www.answers.com/topic/reprisal\#ixzz2D2JNXGPZ, accessed on 23/11/12.

http://www.brainyquote.com/quotes/authors/m/martin_luther_king_jr.html\#vfE5ZJVXkPM xDUbi.99, accessed on 12/12/12.

http://www.goodreads.com/author/quotes/367338.Nelson_Mandela, accessed on 12/12/12.

http://www.hrw.org/news/2010/03/08/nigeria-investigate-massacre-step-patrols, accessed on 5/12/12.

http://www.hrw.org/world-report-2011/nigeria, accessed on 5/12/12.

http://www.punchng.com/news/nigeria-heading-for-disintegration-ex-defence-chief/, accessed on 13/12/12.

http://www.religion-online.org/showchapter.asp?title=799\&C=1038, accessed on 9/10/12. http://www.vanguardngr.com/2012/08/northern-economy-collapsing-northern-govs-cryout/, accessed on 13/12/12. 